ISSN ............... (Print)

ISSN................. (Online)

Journal of Elementary Educational Research

http:// http://ejournal.iain-manado.ac.id/index.php/jeer

Volume 1, No. 1, Juni 2021, pp. 1-8.

\title{
Media Kartu Untuk Meningkatkan Hasil Belajar Matematika Sekolah Dasar
}

\section{Card Media to Improve Elementary School Math Learning Outcomes}

\author{
Annisa Mawarni Bone ${ }^{1^{*} \text { ) }}$ \\ 1)PGMI, FTIK, IAIN Manado, Indonesia
}

\begin{abstract}
Abstrak
Penelitian ini bertujuan untuk meningkatkan hasil belajar siswa kelas IV di SD Al Khairaat Airmadidi Atas dengan menggunakan media kartu. Subyek dalam penelitian ini adalah siswa kelas IV SD Al Khairaat Airmadidi Atas Tahun Pelajaran 2020/2021 yang berjumlah 20 orang, terdiri atas 7 orang perempuan dan 13 orang laki-laki dan guru wali kelas sebagai observator. Instrumen yang digunakan untuk pengumpulan data dalam penelitian ini adalah lembar observasi aktivitas siswa dan guru serta tes hasil belajar. Data hasil penelitian dianalisis dengan menggunakan data kualitatif dan data kuantitatif. Hasil analisis data menunjukkan peningkatan aktivitas guru, aktivitas siswa dan hasil belajar siswa dari siklus I ke siklus II melalui pembelajaran dengan menggunakan media kartu. Pada siklus I rata-rata penilaian aktivitas guru sebesar 3.42\% meningkat menjadi 4\%, aktivitas siswa dalam pembelajaran sebesar 3.21\% meningkat menjadi 3.75\%, dan siswa yang mengalamiu ketuntasan sebesar 35\% meningkat menjadi 95\% pada siklus II. Jadi, dengan demikian dapat disarankan guru sebaiknya dapat mengatur waktu dan materi yang akan diberikan dalam penggunaan media kartu agar semua kegiatan pembelajaran dapat berjalan sesuai yang telah direncanakan, dan dapat meningkatkan hasil belajar siswa pada mata pelajaran matematika.
\end{abstract}

Kata Kunci: Media Kartu, Hasil Belajar, Sekolah Dasar

\begin{abstract}
This study aimed to improve the learming outcomes of fourth-grade students at SD AI Khairaat Airmadidi Atas by using the card as media. The subjects in this study were the fourth-grade students of SD Al Khairaat Airmadidi Atas Academic Year 2020/2021, consisting of 20 students ( 7 female students and 13 male students), and the homeroom teacher as an observer. The data collection instruments in this study were student and teacher activity observation sheets and learning outcomes tests. The gained data were analyzed using qualitative and quantitative methods. The results of data analysis showed an increase in teacher activity, student activity, and student learning outcomes from cycle I to cycle I through learning by using cards. In the first cycle, the average assessment of teacher activity was 3.42\%, which increased to $4 \%$ in the second cycle. Student activity in learning was 3.21\%, increased to $3.75 \%$ in the second cycle. Students who obtained completeness were 35\% increased to 95\% in the second cycle. in conclusion, it can be suggested that teachers should manage the time and material given in the use of cards so that all learning activities can run as planned and improve student learning outcomes in mathematics.
\end{abstract}

Keywords: Cards Media, Learning Outcomes, Elementary School

Disumbit (9 September), Direview (9 September), Diterima (21 September)

How to Cite: Bone, A. M. (2021). Media Kartu Untuk Meningkatkan Hasil Belajar Matematika Sekolah Dasar. JEER: Journal of Elementary Educational Research Vol 1 (1): 1-8.

${ }^{*}$ Corresponding author:

E-mail: annisamawarnibone21@gmail.com 


\section{PENDAHULUAN}

Matematika adalah salah satu ilmu yang sangat penting. Banyak hal di sekitar kita yang berhubungan dengan matematika. Mencari nomor rumah seseorang, menelepon, jual beli barang, menukar uang, mengukur jarak dan waktu, dan masih banyak lagi. Karena ilmu ini sedemikian penting, maka konsep dasar matematika yang benar yang diajarkan kepada seorang anak haruslah benar dan kuat. Paling tidak hitungan dasar yang melibatkan penjumlahan, pengurangan, perkalian, dan pembagian harus dikuasai dengan sempurna. Setiap orang, siapapun dia, pasti bersentuhan dengan salah satu konsep diatas dalam kesehariannya (Setyono, 2007).

Manfaat belajar matematika pada dasarnya dapat dilihat dari tujuan umum pengajaran matematika itu sendiri. Manfaat matematika setelah belajar soalsoal pemecahan masalah, karena pada soal-soal pemecahan masalah materi matematika dihubungkan dengan kehidupan nyata sehari-hari, sehingga pembelajaran dirasakan lebih kontekstual. Siswa menyadari dengan baik akan pentingnya menguasai metematika sebagai bekal dalam menjalani kehidupannya di masa mendatang (Offirstson, 2014).

Pembelajaran guru juga memerlukan peran guru untuk bisa mendidik peserta didik. Peran orang tua dalam memberikan motivasi kepada anak-anaknya dalam mempelajari matematika sangat dibutuhkan karena masih banyak siswa yang mengalami kesulitan dalam mempelajari mata pelajaran matematika. Siswa- siswa yang mengalami kesulitan dalam belajar dapat ditolong dengan memberikan bimbingan sebaik-baiknya. Tentu saja dukungan dari orang tua sangat mempengaruhi semangat belajar anak. Orang tua juga dapat memberikan motivasi-motivasi belajar untuk anakanaknya, salah satunya memberikan pengertian tentang pentingnya belajar matematika, dengan memberikan fasilitas yang memadai sehingga anak-anaknya dapat belajar matematika dengan baik (Budiyanto, 2003).

Materi pecahan merupakan salah satu materi penting yang diajarkan pada Sekolah Dasar. Bilangan pecahan adalah bilangan yang menggambarkan bagian dari keseluruhan yang dilambangkan dengan $\frac{a}{b}$ dalam hal ini, a disebut sebagai $b$ pembilang dan b sebagai penyebut (Fujita, 2011). Pecahan adalah suatu bilangan yang merupakan hasil bagi antara bilangan bulat dan bilangan asli (Untoro, 2010). Jenis-jenis pecahan seperti pecahan senilai, biasa, campuran, desimal, dan persen.

Pembelajaran mata pelajaran matematika, proses pembelajaran 
matematika perlu mendapat perhatian dan penanganan yang serius. Hal ini penting, sebab hasil observasi masih menunjukkan bahwa proses pembelajaran matematika di sekolah dasar masih belum menunjukkan hasil yang memuaskan. Hal ini dapat dilihat dari hasil ujian akhir semester (UAS) di SD Al-Khairaat Airmadidi Atas, bisa dilihat nilai rata-rata hasil belajar matematika untuk siswa sekolah dasar berkisar antara nilai 6 dan 7, bahkan lebih kecil dari angka ini juga merupakan indikator yang menunjukkan bahwa kemampuan pemahaman siswa terhadap mata pelajaran matematika masih rendah. Padahal, diketahui bahwa dengan pemahaman tersebut siswa mestinya dapat mengkomunisikan masalah matematika. Daya serap rata-rata siswa sekolah dasar untuk mata pelajaran matematika hanya sebesar 35\%.

Rendahnya prestasi belajar matematika siswa tersebut, banyak faktor yang menyebabkannya, misalnya masalah klasik tentang penerapan metode pembelajaran matematika yang masih terpusat pada guru, sementara siswa cenderung pasif. Faktor klasik lainnya, ialah penerapan model pembelajaran konvensional, yakni ceramah, tanya jawab, dan pemberian tugas atau pekerjaan rumah (PR). Sistem pengajarannya menyebabkan siswa tidak berpartisipasi aktif dalam mengikuti pembelajaran, sehingga dikhawatirkan siswa tidak dapat meningkatkan aktivitas belajar matematika untuk meningkatkan pengembangan kemampuannya (Susanto, 2016).

Penelitian yang dilakukan oleh Aprinawati, (2017) menunjukkan bahwa penggunaan media kartu domino bilangan dapat meningkatkan hasil belajar matematika siswa kelas V SD. Penelitian dengan menggunakan media kartu domino bilangan dapat meningkatkan aktivitas guru dan siswa pada setiap pertemuan dalam proses belajar mengajar. Sementara Gosachi \& Japa, (2020) dalam penelitiannya mengungkapkan bahwa model pembelajaran dengan bantuan kartu dapat meningkatkan hasil belajar siswa. Oleh karena itu penting dilakukan penelitian serupa untuk diaplikasikan di SD Al-Khairaat Airmadidi Atas Kecamatan Airmadidi Kabupaten Minahasa Utara.

Mengingat pentingnya media kartu dalam meningkatkan hasil belajar siswa dan juga meningkatkan aktifitas guru dan siswa dalam proses pembelaran maka perlu dilakukan penelitian untuk menelusuri hal tersebut. Dengan demikian, penelitian ini bertujuan untuk mengetahui deskrispi penggunaan media kartu untuk meningkatkan hasil belajar siswa pada 
mata pelajaran matematika siswa kelas IV di SD Al-Khairaat Airmadidi Atas.

\section{METODE PENELITIAN}

Penelitian ini merupakan penelitian tindakan kelas (PTK) yang dalam pelaksanaannya dilakukan dalam 2 siklus dengan proses kajian berdaur ulang yang terdiri dari empat tahapan yaitu perencanaan, tindakan, observasi dan refleksi. Penelitian ini dilaksanakan di SD Al-Khairaat Airmadidi Atas Kecamatan Airmadidi Kabupaten Minahasa Utara pada semester genap Tahun Pelajaran 2020/2021. Penelitian ini dilaksanakan di kelas IV dengan jumlah siswa sebanyak 20 orang yang terdiri atas 7 orang perempuan dan 13 orang laki-laki.

Sumber data dalam penelitian ini adalah siswa kelas IV SD AL-Khairaat Airmadidi dan guru wali kelas IV. Jenis data yang diperoleh dalam penelitian ini ada dua, yaitu data kuantitatif berupa data hasil belajar siswa dan data kualitatif adalah data yang berupa aktivitas guru dan siswa.

Data yang diperlukan dalam penelitian ini meliputi: (1) Data hasil belajar siswa, (2) Data aktivitas guru dan siswa. Data hasil belajar siswa dikumpulkan dengan menggunakan instrumen tes hasil belajar bentuk essay dengan 5 soal dengan skor setiap soal adalah 20. Data ini diperoleh pada akhir setiap siklus I dan siklus II. Sementara itu, data aktivitas guru dan siswa dijaring dengan menggunakan lembar observasi. Pengamatan dilakukan terhadap aktivitas guru dan siswa dengan menggunakan lembar observasi aktivitas guru dan siswa yang disusun berdasarkan indikatorindikator aktivitas guru dan siswa dengan kriteria penilaian terdiri atas 4 option, yaitu skor 1 kurang skor 2 cukup, skor 3 baik, dan skor 4 baik pada akhir pertemuan siklus.

Sebelum instrumen-instrumen ini digunakan dalam pengambilan data penelitian terlebih dahulu dikonsultasikan dengan pembimbing, khusus untuk instrumen tes hasil belajar selain dikonsultasikan dengan pembimbing juga dikonsultasikan dengan guru wali kelas IV SD Al-Khairaat Airmadidi Atas untuk mengetahui tingkat kelayakan butir-butir tes yang akan digunakan.

Penelitian ini menggunakan teknik analisis data kuantitatif dan kualitatif. Data kualitatif diperoleh dari data non-tes yaitu lembar panduan observasi. Data hasil observasi digunakan untuk mengetahui aktivitas siswa dan kinerja guru setelah diterapkan media kartu. Data tersebut diperoleh berdasarkan perilaku yang sesuai dengan tujuan pembelajaran. Data diperoleh dengan pengamatan aktivitas siswa selama kegiatan pembelajaran. Data 
kuantitatif diperoleh dari hasil tes yang dikerjakan siswa pada siklus I dan siklus II dengan memperhatikan aspek ketuntasan, yaitu KKM.

\section{HASIL DAN PEMBAHASAN}

Hasil penelitian akan diuraikan berdasarkan hasil pra siklus, siklus I, dan siklus II.

\section{Hasil pra siklus}

Hasil pra siklus ini diambil dengan cara memberikan tes hasil belajar kepada siswa pada awal pertemuan. Pra siklus dilakukan untuk menetukan skor awal terhadap hasil belajar matematiksa dari siswa sebelum melakukan siklus I. Hasil penelitian pada tahap pra siklus terlihat bahwa 5 siswa yang mencapai ketuntasan belajar dengan ketuntasan belajar 25\% dengan nilai rata-rata 51 dan jumlah nilai 1.020 hasil ini masih dikategorikan sangat rendah. Berdasarkan hasil penelitian pra siklus di atas dapat diketahui bahwa prestasi belajar siswa pada mata pelajaran matematika ini pada siswa kelas IV SD AlKhairaat Airmadidi Atas rendah.

Setelah dilakukannya analisis dan refleksi pada tahap pra siklus ini tindakan peneliti merumuskan penyebab timbulnya masalah tersebut. Hasil dari observasi peneliti pada siswa kelas IV bahwa mereka menganggap bahwa mata pelajaran matematika adalah pelajaran yang sulit dan tidak menyenangkan, apa lagi bagi siswa-siswa yang sulit dalam mempelajari matematika. Banyak siswa yang bosan ketika pembelajaran sedang berlangsung, sering kali siswa tidak mendengar apa yang dijelaskan dari materi, dan ada juga yang sedang asyik dengan permainan mereka sendiri. Guru sekali menegur siswa yang tidak memperhatikan penjelasan dari guru dan memberi motivasi kepada siswa agar siswa bersemangat untuk belajar. Melihat kondisi ini peneliti tertarik untuk memperbaiki rendahnya hasil belajar siswa dengan menggunakan media kartu.

\section{Hasil Siklus I}

Pada tahap siklus I terdapat 7 siswa yang telah mencapai ketuntasan belajar dengan nilai 35\% dengan nilai rata-rata 64.5 dengan jumlah nilai 1.290 hasil ini masih belum berhasil karena belum mencapai nilai rata-rata 70. Dalam hal ini penggunaan media kartu ini belum bisa meningkatkan hasil belajar siswa karena belum mencapai standar kelulusan yaitu 70 maka peneliti melakukan tindakan II di siklus selanjutnya.

Hasil observasi menunjukkan bahwa pada awalnya siswa terlihat kurang memperhatikan dikarenakan mereka tidak pernah menggunakan media saat belajar. Walaupun demikian ada beberapa siswa yang tetap aktif mendengarkan dan mengikuti pembelajaran. Hal ini disebabkan karena pada mata pelajaran 
matematika ini belum pernah diterapkan media kartu sehingga pada saat diterapkan respon dari siswa sangatlah baik sehingga dapat meningkatkan hasil belajar siswa.

Hasil dari pra siklus ke siklus I hanya meningkat 10\%, karena siswa belum sepenuhnya memahami materi bilangan pecahan sehingga nilai mereka masih di bawah rata-rata. Maka dari itu peneliti mengambil tindakan agar hasil dari siswa bisa mencapai KKM. Peneliti mempunyai solusi yaitu media kartunya diwarnai agar siswa dapat fokus dalam pembelajaran dan peneliti mendekati para siswa dan menjelaskan kembali apa yang siswa belum pahami.

\section{Hasil Siklus II}

Pada siklus II terlihat sudah hampir semua siswa yang mencapai ketuntasan belajar dengan nilai ketuntasan hasil belajar sudah mencapai 95\% dengan nilai rata-rata 79 dengan jumlah nilai 1580 . Sedangkan aktivitas guru dan siswa lebih meningkat dari siklus sebelumnya. Dalam hal ini penggunaan media kartu ini sudah berhasil meningkatkan hasil belajar siswa karena telah mencapai standar kelulusan yaitu 70 maka peneliti tidak melanjutkan pada siklus selanjutnya.

Observasi dilaksanakan secara langsung sesuai dengan pelaksanaan kegiatan belajar mengajar seperti yang dilakukan pada siklus I. adapun perbedaan pada siklus II adalah siswa lebih aktif sebab mereka sudah terbiasa pada pembelajaran matematika dengan menggunakan media kartu dan siswa dari siklus I adalah 3.21 dan 3.42 dan masih dikatakan cukup dan lebih meningkat pada siklus II yakni 3.75 dan 4 .

Pada siklus I rata-rata aktivitas belajar siswa masih kurang, tetapi pada siklus II mengalami peningkatan. Hal ini tampak dari kesiapan siswa pada siklus I hanya mencapai $3.05 \%$ pada siklus II meningkat menjadi 3.55\%, memperhatikan penjelasan guru tentang memahami konsep pecahan dengan menggunakan media kartu saat pembelajaran pada siklus I hanya mencapai $2.9 \%$ pada siklus II meningkat menjadi 3.65\%, memperhatikan guru dalam mempertunjukkan media kartu pada siklus I mencapai $3.15 \%$ pada siklus II meningkat menjadi $3.75 \%$, keaktifan siswa dalam mempraktekkan operasi hitung pecahan pada siklus I hanya mencapai $3.4 \%$ pada siklus II meningkat menjadi $3.85 \%$, keaktifan siswa dalam menyelesaikan tugas pada siklus I hanya mencapai $3.55 \%$ pada siklus II meningkat menjadi $3.95 \%$. jadi, dengan demikian terlihat adanya peningkatan aktivitas belajar siswa pada saat pembelajaran dengan menggunakan media kartu. 
Selain itu, hasil belajar siswa pada siklus II ini terjadi peningkatan. Hal ini diindikasikan dengan ketuntaasan belajar secara klasikal mencapai 95\% naik besar $35 \%$ dari siklus I yang hanya mencapai ketuntasan belajar secara klasikal 45\%. Jika dibandingkan dengan hasil pre tes maka hasil belajar peserta didik pada siklus II ini secara tidak langsung berdampak pula pada peningkatan nilai rata-rata kelas siswa dimana pada saat pre tes nilai yang diperoleh hanya 51, siklus I diperoleh 64,5 dan pada siklus II meningkat menjadi 79. Apabila mengacu pada kriteria hasil belajar sebagaimana dipaparkan dalam bab III, maka pada saat pre tes dan siklus I hasil belajar siswa masuk kriteria tidak tuntas dan pada siklus II masuk kriteria tuntas. Berdasarkan penjelasan di atas dapat disimpulkan bahwa penggunaan media kartu dapat meningkatkan hasil belajar matematika siswa.

Berdasarkan pendapat Komariyah (2008) dari menjelaskan bahwa media kartu adalah media yang berisi gambargambar yang dapat menarik perhatian siswa dalam belajar. Jadi, dalam pembelajaran, anak-anak sangat tertarik dengan media kartu jika disesuaikan dengan kebutuhan dasar mereka. Hal ini dapat dibuktikan melalui penelitian yang peneliti lakukan bahwa hasil belajar siswa meningkat.

Aprinawati, (2017) menyebutkan bahwa media kartu bilangan mempunyai keistimewaan yakni dapat mempermudah guru dalam mengajarkan suatu materi pelajaran matematika. Sementara Gosachi \& Japa, (2020) menjelaskan bahwa media kartu dalam pembelajaran dapat menuntut siswa untuk aktif mencari jawaban atau pertanyaan dari kartu gambar yang mereka dapatkan, menarik perhatian siswa dan menumbuhkan rasa ingin tau siswa dalam proses pembelajaran dan meminimalisir kesulitan belajar secara individu yang sering dialami oleh siswa. Dengan demikian media kartu dalam pembelajaran dapat memberikan banyak manfaat kepada siswa maupun guru.

\section{SIMPULAN}

Berdasarkan hasil dan pembahasan maka dapat disimpulkan bahwa melalui penggunaan media kartu dapat meningkatkan hasilbelajar matematika siswakelas IV SD Al-Khairaat Airmadidi Atas. Berdasarkan hasil observasi sebelum menggunakan media kartu hasil belajar siswa pada data awal sebelum tindakan, hasil belajar siswa diperoleh rata-rata 51 . Kemudian berdasarkan hasil observasi pada siklus pertama yang menunjukkan bahwa tingkat hasil belajar siswa mencapai dengan nilai rata-rata 64,5. 
Sedangkan pada siklus II terjadi peningkatan mencapai minat belajar siswa diperoleh rata-rata 80,5 . Keberhasilan ini dapat tercapai dipengaruhi oleh penggunaan media kartu, aktivitas siswa menjadi lebih aktif yang berarti siswa cenderung positif dalam mengikuti proses pembelajaran yang diberikan oleh guru berdasarkan hasil pengamat aktivitas guru dan siswa siklus I dan siklus II.

\section{DAFTAR PUSTAKA}

Aprinawati, I. (2017). Penggunaan Media Kartu Domino Bilangan untuk Meningkatkan Hasil Belajar Matematika Siswa Kelas V SD. Jurnal Pelangi, 9(2), 123-134. https://doi.org/10.22202/jp.2017.v9 i2.1900

Budiyanto, W. (2003). Dukungan Perhatian Orang Tua.

Fujita, K. (2011). Moonlight act:Buku 1, Volume 1. PT Grafindo Media Pratama.

Gosachi, I. M. A., \& Japa, I. G. N. (2020). Model Pembelajaran Make A Match Berbantuan Media Kartu Gambar Meningkatkan Hasil Belajar Matematika. Jurnal Pedagogi Dan Pembelajaran, 3(2), 152. https://doi.org/10.23887/jp2.v3i2.2 5260

Komariyah, K. (2008). Penggunaan Media Kartu Bilangan untuk Meningkatkan Hasil Belajar Penjumlahan dan Pengurangan Bilangan Pecahan pada Mata Pelajaran Matematika Siswa Kelas V SD Al-amin Surabaya. State University of Surabaya.

Offirstson, T. (2014). Aktivitas pembelajaran matematika melalui inkuiri berbantuan software cinderella. Yogyakarta: Deepublish.

Setyono, A. (2007). Mathemagics. Gramedia Pustaka Utama.
Susanto, A. (2016). Teori belajar dan pembelajaran di sekolah dasar. Kencana.

Untoro, J. (2010). Buku Pintar Pelajaran SD/MI 5 In 1. WahyuMedia. 